\title{
FERMENTED Moringa oleifera SEEDS ENHANCED WITH Euchema cottonii AS AN ALTERNATIVE TEMPEH: ORGANOLEPTIC ANALYSIS, PROTEIN, AND FIBER CONTENT
}

\author{
Nurhaeni $^{1}$, D. Darwis ${ }^{2}$ and P. Satrimafitrah ${ }^{1, \bowtie}$ \\ ${ }^{1}$ Department of Chemistry, Faculty of Mathematics and Natural Sciences, Tadulako \\ University, Palu-94148, (Central Sulawesi) Indonesia \\ ${ }^{2}$ Department of Physics, Faculty of Mathematics and Natural Sciences, Tadulako University, \\ Palu-94148, (Central Sulawesi) Indonesia \\ ${ }^{\circledR}$ Corresponding Author: pasjan82@gmail.com
}

\begin{abstract}
A study of new tempeh produced from Moringa oleifera seeds fermented with commercial yeast and the addition of Euchema cottonii was performed. The study was designed to utilize M. oleifera seeds as an alternative material for tempeh, to determine its protein and fiber content, as well as organoleptic analysis. Tempeh was produced with a variation ratio of commercial yeast and fermentation time. The ratio of $M$. oleifera seeds: E. cottonii was varied to explore the most suitable composition for consumers. Protein and fiber content analysis was determined following reference methods. Results indicated that 24 hours' fermentation using 1-gram commercial yeast produced the highest protein (20.57\%). M. oleifera seeds: E. cottonii ratio of 70:30 was the most preferred tempeh with a hedonic value of 3.76. Forty-eight hours' fermentation with 3-grams commercial yeast yielded maximum fiber content. It can be concluded that this alternative tempeh is a good alternative for soybean tempeh as it contains high proteins and fibers.
\end{abstract}

Keywords: Tempeh, Moringa oleifera, Euchema cottonii, Fermentation, Protein and Fiber Content, Organoleptic Analysis.

RASĀYAN J. Chem., Vol. 14, No.1, 2021

\section{INTRODUCTION}

Food processing industry faces rising demands to develop diverse and healthy foods as new food products. Food can be processed in several ways, including fermentation, which involves the utilization of microorganisms. ${ }^{1-3}$ Fermentation offers new food that varies with not only nutritional and functional values but also enriched taste as a must-have attribute. One of the well-known fermented food in Indonesia is Tempeh ${ }^{4}$. Tempeh is traditionally produced using soybean fermented with Rhizopus, but it can also be produced using other substrates, such as corn, rice, barley, and white beans. ${ }^{5-6}$

Moringa oleifera is an indigenous plant found in African and Asian countries, like India and Indonesia ${ }^{7}$. Roots, stems, leaves, flowers, and seeds of M. oleifera are consumed by humans. High amounts of protein, minerals, and antioxidant compounds contained in its leaves have attracted researchers to study and produce medicines. The seeds also contain high-quality fatty acids, protein, and carbohydrates. ${ }^{8-9}$ Nutritional content of $M$. oleifeira seeds has been widely reported, but to date, little is known about fermented seeds of $M$. oleifeira and their acceptance by the consumer as functional foods. The advantage of using moringa seed instead of soybean is cost-effective, since in Indonesia, mostly soybeans are imported from overseas. ${ }^{10}$

Euchema cottonii (E. cottonii) is carrageenan-producing seaweed with valuable nutritional content. It is high in ash and dietary fiber, but low in lipid. It is also high in vitamin $\mathrm{C}$, alpha-tocopherol, and several minerals. ${ }^{11}$ The utilization of seaweed enhances the fortification of food products, influencing the physical properties, chemical components, and organoleptic qualities of food. ${ }^{12}$ Product development needs to be directed to create a new product that has more benefits and can be enjoyed by people from various circles.

In this article, new tempeh from Moringa oleifera seeds fortified with seaweed as additional material has been produced by fermentation to find out the nutritional values, particularly protein and fiber contents, and sensory acceptance. 


\section{Materials}

\section{EXPERIMENTAL}

Commercial yeast (Raprima), distilled water, $\mathrm{NaOH}$ (Merck), ethanol (Merck), $\mathrm{HCl}$ (Merck), n-hexane (Merck), Whatman filter paper 41 (GE healthcare) were purchased. Seeds were collected from $M$. oleifera tree surrounding Tadulako University. E. cottonii was from coastal area of Morowali district.

\section{Preparation of Moringa seeds Tempeh}

$M$. oleifera seeds were prepared with or without the addition of $E$. cottonii. Seeds were soaked in clean and sterile water for 12 hours, peeled, boiled for 45 minutes, drained, and air-dried at room temperature. E. cottonii was washed with clean water and dried under the sun, washed again with running water and soaked for 1 week in lime water. It was washed again using clean water and cut into small pieces to a size of $\pm 0.5 \mathrm{~cm}$. As much as $100 \mathrm{~g}$ of dried seeds were added with $1 \mathrm{~g}, 2 \mathrm{~g}$, and $3 \mathrm{~g}$ of commercial yeast and stirred evenly. Mixtures of seeds and yeast at different ratios were fermented for varied periods of $24 \mathrm{~h}, 36 \mathrm{~h}, 48 \mathrm{~h}$, and $72 \mathrm{~h}$.

\section{Protein Content Analysis}

Total protein content was measured using the Kjeldahl method as follows: 0.5 grams Tempeh sample was boiled in a Kjeldahl flask containing 1.2 grams of mixed catalyst (Kjeldahl powder) and $10 \mathrm{~mL}$ concentrated $\mathrm{H}_{2} \mathrm{SO}_{4}$, until the solution turned greenish and clear. The solution was diluted 10 times. 5 $\mathrm{mL}$ of the diluted sample was added to $30 \% \mathrm{NaOH}$ in a distilling flask and mixed with 4 drops of Phenolphthalein. The neutralization reaction was run for 5-10 minutes, and ammonia gas that was formed was collected in a receiving flask containing $2 \%$ boric acid. Nitrogen content was estimated by titration with $0.01 \mathrm{~N} \mathrm{HCl}$.

$$
\text { Protein Content }(\%)=\frac{(V 1-V 2 \times N \times 14.007 \times 6.25)}{W} \times 100 \%
$$

(V1 and V2 are titration volume of sample and blank; 14.007 gram is molecular weight (MW) of Nitrogen; $\mathrm{N}$ is normality of $\mathrm{HCl}$; and $\mathrm{W}$ is the weight of the sample; 6.25 is protein factor for food.)

\section{Crude Fiber Content Analysis}

Crude fiber content was determined by a gravimetric method based on ISO 5498:1981. ${ }^{13}$

Ten grams of sample was dried at $80^{\circ} \mathrm{C}$ for $1 \mathrm{~h}$. Lipid content was extracted using hexane for 6 hours using a Soxhlet extractor. After distillation, extracted lipid was dried at $105^{\circ} \mathrm{C}$. Lipid-free sample was boiled for 30 minutes, with $25 \mathrm{~mL} 1.25 \%$ sulphuric acid. Twenty-five $\mathrm{mL} 3.25 \% \mathrm{NaOH}$ was added, and the boiling process continued for 30 minutes. Next, the mixture was filtered using Buchner funnel containing Whatman filter paper no 41. Sediment was rinsed with $1.25 \% \mathrm{H}_{2} \mathrm{SO}_{4}$, hot aquadest, and $96 \%$ ethanol, respectively. Sample in filter paper was placed in a petri dish and dried at $105{ }^{\circ} \mathrm{C}$ for 1 hour.

$$
\text { Fiber Content }(\%)=\frac{W 2-W 1}{W} \times 100 \%
$$

(W is sample initial weight; $\mathrm{W} 1$ is the weight of petri dish and filter paper; $\mathrm{W} 2$ is the weight of petri dish and filter paper + dried residue.)

\section{Organoleptic Analysis}

An organoleptic test was performed to test the aroma, texture, and color of tempeh. The test was carried out using the hedonic test method by giving 4 tempeh samples ( 3 treatment samples and 1 control sample). As many as 25 people (students, age of 20-23, and lecturers, age of 30-50) were asked to provide an assessment of the tempeh quality characteristics presented by writing their level of preference on a numerical scale of 1 (dislike) to 5 (like very much).

\section{Protein Content}

\section{RESULTS AND DISCUSSION}

M. oleifera seeds were fermented for $24,36,48$, and 72 hours with various amounts of commercial yeast (Raprima), which contains Rhizopus oligosporus. Kjeldahl method was performed as generally used for protein analysis in foods. ${ }^{14}$ The highest protein content $(20.57 \%)$ was obtained at 24 hours of fermentation time with $1 \mathrm{~g}$ yeast (Fig.-1). The lowest protein content $(7.60 \%)$ was obtained at 72 hours 
of fermentation with $3 \mathrm{~g}$ yeast. According to the Indonesian National Standard (SNI 3144:2009) soybean tempeh quality requirements should have a minimum protein content of $16 \%{ }^{15}$. Fermented tempeh with yeast weight as much as $0.5 \mathrm{~g}$ was also tested, but during the 24-hour fermentation, mycelia grew only slightly and unevenly due to inadequate substrate used by yeast to grow (data not shown). Besides, 72 hours of fermentation of tempeh yielded unpleasant odor and softer texture, caused by damage to the fungus found in tempeh and the action of lipoxygenase enzymes. ${ }^{16}$

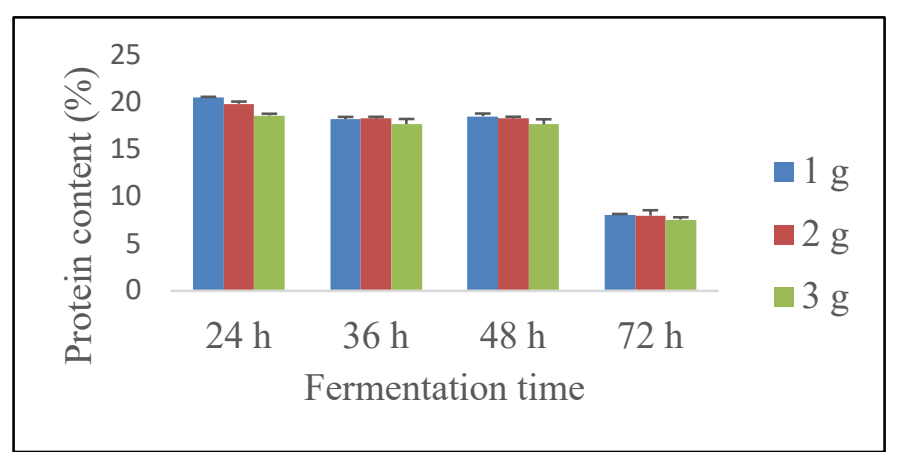

Fig-1: Total Protein Content of Fermented M. oleifera seeds.

Seaweed, E. cottonii, was incorporated at varied ratios to increase the quality of tempeh. Seaweeds, like E. cottonii are used in the production of carrageenan that is applied in pharmaceutics, cosmetics, and food industries. ${ }^{17-18}$ Carrageenan has a high viscosity and gelling properties, which are essential as texture modifiers. ${ }^{19}$ Furthermore, seaweeds also contain fibers and minerals that aid in reducing the utilization of salt. The incorporation of seaweed extract will help as a natural preservative for tempeh. ${ }^{20}$

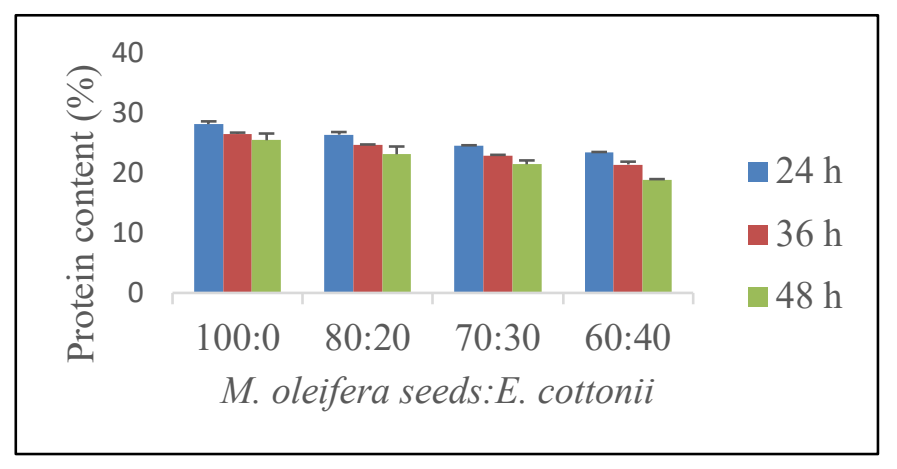

Fig-2: Total Protein Content of M. oleifera seeds:E. cottonii.

The results indicated that the more the seaweed, the lower was the protein content produced. Likewise, the longer the fermentation, the lower was the protein content produced. A decrease in protein content in tempeh is caused by several factors, specifically the addition of ingredients, heating (boiling/steaming), and fermentation time. ${ }^{21}$ In these findings, the addition of seaweed affects the protein content produced by M. oleifera seed (Fig. 2). The highest protein contents were obtained at the ratio of $M$. oleifera seeds to E. cottonii 100: 0 (26.51\%), and at 24-hour fermentation time $(25.705 \%)$. During the fermentation process, generally, proteins are degraded into simple peptides. The longer fermentation, the more proteins degraded. Also, there is an increase in the number of amino acids, and many molds are actively breaking down complex compounds. ${ }^{22}$ After the fermentation process, the total content of amino acids decreases, but free amino acids will increase sharply; this is because mold from commercial yeast uses amino acids as a source of nitrogen for its growth. ${ }^{23} \mathrm{~A}$ decrease in the content of tempeh seeds of $M$. oleifera and seaweed before reaching the optimum value can be due to the high carbohydrate content of seaweed, which consists of seaweed polysaccharide components, such as agar and carrageenan, which can form a gel affecting the fermentation process.

\section{Organoleptic Assay}

An organoleptic assay was performed to assess the quality of moringa seeds tempeh. ${ }^{24}$ Organoleptic tests on $M$. oleifera seeds tempeh with different seaweed ratios can be evaluated by the appearance, 
RASĀYAN J. Chem.

Vol. 14 | No. 1 |155-160| January - March | 2021

aroma, texture, and color of the product. Panel response to this organoleptic test was obtained from 25 panelists (Table-1). In the food industry, testing of aroma is considered vital because it can quickly provide an assessment of the product regarding whether or not the product is accepted. Besides, it also serves as an indicator of damage to the product. ${ }^{25}$ Hence, the aroma was one of the analysis parameters used to clarify the level of tempeh preference. The ratio of seeds and seaweed can change the level of tempeh preference, so the tempeh aroma test is required to determine the tempeh with the preferred aroma. Tempeh at the ratio of 70:30 was the most chosen by the panelists, with a hedonic value of 3.76 which was slightly liking the aroma of tempeh. The pungent aroma produced in seeds is pure from the distinctive aroma of M. oleifera.

\begin{tabular}{|c|c|c|c|c|c|c|c|c|c|}
\hline \multirow{4}{*}{ Panelist } & \multicolumn{9}{|c|}{ Seeds: Seaweed Ratio (g) } \\
\hline & \multicolumn{3}{|c|}{$80: 20$} & \multicolumn{3}{|c|}{$70: 30$} & \multicolumn{3}{|c|}{$60: 40$} \\
\hline & \multicolumn{9}{|c|}{ Score (1-5) } \\
\hline & Aroma & Color & Texture & Aroma & Color & Texture & Aroma & Color & Texture \\
\hline 1 & 4 & 3 & 4 & 4 & 4 & 4 & 2 & 3 & 3 \\
\hline 2 & 3 & 3 & 3 & 4 & 4 & 4 & 3 & 3 & 3 \\
\hline 3 & 3 & 4 & 3 & 4 & 5 & 4 & 2 & 3 & 3 \\
\hline 4 & 3 & 3 & 3 & 4 & 4 & 5 & 3 & 2 & 4 \\
\hline 5 & 4 & 3 & 3 & 4 & 5 & 4 & 3 & 2 & 3 \\
\hline 6 & 4 & 4 & 4 & 4 & 5 & 5 & 2 & 2 & 3 \\
\hline 7 & 3 & 4 & 4 & 4 & 4 & 3 & 2 & 3 & 2 \\
\hline 8 & 3 & 4 & 4 & 4 & 3 & 4 & 3 & 3 & 2 \\
\hline 9 & 5 & 4 & 3 & 4 & 3 & 4 & 3 & 3 & 2 \\
\hline 10 & 3 & 4 & 3 & 3 & 4 & 5 & 2 & 4 & 3 \\
\hline 11 & 3 & 5 & 4 & 4 & 4 & 4 & 2 & 3 & 3 \\
\hline 12 & 4 & 4 & 4 & 4 & 5 & 4 & 4 & 3 & 3 \\
\hline 13 & 3 & 4 & 4 & 4 & 4 & 4 & 2 & 3 & 3 \\
\hline 14 & 3 & 4 & 4 & 4 & 4 & 5 & 3 & 4 & 4 \\
\hline 15 & 4 & 4 & 3 & 3 & 4 & 3 & 3 & 3 & 2 \\
\hline 16 & 5 & 4 & 4 & 3 & 4 & 5 & 2 & 3 & 3 \\
\hline 17 & 4 & 4 & 4 & 3 & 5 & 4 & 3 & 2 & 3 \\
\hline 18 & 3 & 3 & 4 & 5 & 4 & 4 & 2 & 3 & 3 \\
\hline 19 & 3 & 3 & 4 & 4 & 4 & 4 & 2 & 3 & 3 \\
\hline 20 & 3 & 3 & 4 & 4 & 3 & 4 & 2 & 2 & 3 \\
\hline 21 & 4 & 4 & 3 & 3 & 3 & 4 & 3 & 3 & 2 \\
\hline 22 & 4 & 3 & 4 & 5 & 4 & 4 & 3 & 4 & 2 \\
\hline 23 & 3 & 4 & 4 & 3 & 5 & 5 & 4 & 3 & 3 \\
\hline 24 & 4 & 4 & 5 & 3 & 4 & 4 & 3 & 3 & 3 \\
\hline 25 & 4 & 4 & 4 & 3 & 4 & 4 & 3 & 3 & 3 \\
\hline
\end{tabular}

(1 dislike, 2 dislike slightly, 3 like slightly, 4 like moderately, 5 like very much)

Texture has complex properties and is related to the structure of the material, which consists of three elements, namely mechanical (hardness, elasticity), geometric (sandy, crummy), and mouthfeel (oily, watery). The dense texture of tempeh is influenced by the percentage of the addition of seaweed. The greater percentage of seaweed can form more mycelium so that mold hyphae grow intensively and evenly to form a braid that binds one seed to another so that it becomes compact, dense, and hard. ${ }^{26}$ Carrageenan present in E. cottonii is a hydrocolloid compound with the ability to bind water. So higher the percentage of seaweed, the harder is the texture of tempeh. ${ }^{27}$ Tempeh at the ratio of 70:30 yielded a hedonic value of 4.16 which is considered as moderately liked.

Table-2: Hedonic Test of Tempeh

\begin{tabular}{c|c|c|c}
\hline \multirow{2}{*}{ Organoleptic } & \multicolumn{3}{|c}{ Seeds: Seaweed (g) } \\
\cline { 2 - 4 } & $80: 20$ & $70: 30$ & $60: 40$ \\
\hline & \multicolumn{3}{|c}{ Hedonic Value } \\
\hline Aroma & 3.56 & 3.76 & 2.64 \\
\hline Color & 3.72 & 4.08 & 2.92 \\
\hline Texture & 3.72 & 4.16 & 2.84 \\
\hline
\end{tabular}


Determination of the quality of food, in general, is dependent on several factors, including aroma, texture, and color. However, before other factors are considered, first visual appearance and color greatly determine consumer acceptance and also provide a clue about chemical changes in food. Typically, tempeh has a compact white color and dense mushrooms. ${ }^{28}$ This formation of the white color is due to the dense mycelium braid formed by mold species Rhizopus $s p$. in the tempeh. Good quality tempeh has clean white characteristics that are evenly distributed on its surface. The organoleptic analysis showed that the ratio of 70:30 was the most preferable, with an average value of 4 (Table-2).

\section{Fiber Content}

After determining that the ratio of 70:30 was the most preferable the tempeh, investigation was continued to calculate its fiber content. The longer the fermentation time, the higher was the fiber content produced (Fig.-3). Due to processing soybeans into tempeh, nitrogen levels and cellulose levels increase. ${ }^{29}$ The increasing amount of commercials yeast also produced higher fiber content in seeds. ${ }^{30}$ As seen in Fig.-3, the highest amount of fiber produced was by 3 grams of commercial yeast fermented for 48 hours.

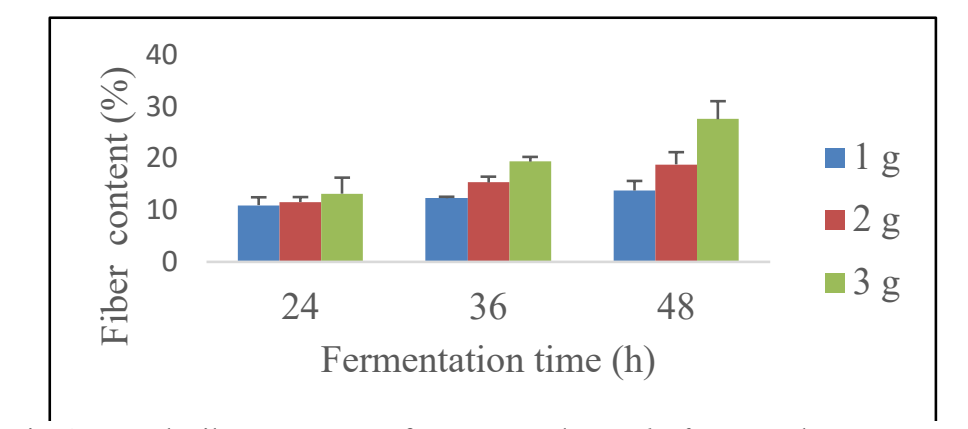

Fig-3: Total Fiber Content of Fermented M. oleifera Seeds: E. cottonii

\section{CONCLUSION}

The current study reports the successful preparation of novel tempeh using $M$. oleifera seeds as primary material and $E$. cottonii as a food additive. The protein and fiber contents meet the national standard of Indonesia (SNI) and were moderately liked by consumers. The best condition to obtain the preferable tempeh was 24-hour fermentation with $1 \mathrm{~g}$ commercial yeast and addition of $3 \mathrm{~g}$ seaweed with seeds and seaweed ratio of 70:30. Further studies are required to find out its amino acid profiles and bioactive compounds.

\section{ACKNOWLEDGMENT}

Special gratitude to the Faculty of Mathematics and Natural Sciences, Tadulako University, for supporting facilities and to Nurdiana, Oktavita, and Meldiana for their technical assistance.

\section{REFERENCES}

1. N. Terefe, Food Fermentation, Reference Module in Food Science, Elsevier BV, p.1 (2016), DOI: 10.1016/B978-0-08-100596-5.03420-X

2. R. Agustini, I.G.M Sanjaya, A. Sabarudin, A. Widodo, Rasayan Journal of Chemistry, 12(4), 2348(2019), DOI:10.31788/RJC.2019.1245411

3. T. D. Olawole, A.T. Olalere, O.A. Adeyemi, O. Okwumabua, I. S. Afolabi, Rasayan Journal of Chemistry, 12(2), 523(2019), DOI: 10.31788/RJC.2019.1224066

4. N. Nakajima, N. Nozaki, K. Ishihara, A. Ishikawa, H. Tsuji, Journal of Biosciences and Bioengineering. 100, 685(2005), DOI:10.1263/jbb.100.685

5. A. Krisnawati, M. M. Adie, Procedia Food Science, 3, 355(2015), DOI:10.1016/j.profoo.2015.01.039

6. R. J. Vital, P.Z. Bassinello, Q. A. Cruz, R. N. Carvalho, J. C. M. de Paiva, A. O. Colombo, Foods, 7, 9 (2018), DOI:10.3390/foods7090136

7. A. Leone, A. Spada, A. Baterazzi, A. Schiraldi, J. Aristil, S. Bertoli, International Journal of Molecular Sciences, 16, 12791(2015), DOI:10.3390/ijms160612791

8. F. Anwar, M. Ashraf, M.I. Bhanger, Journal of American Oil Chemist' Society, 82, 45(2005), DOI: $10.1007 / \mathrm{s} 11746-005-1041-1$

9. J.T.A. Oliveira, S.B. Silveira, I.M. Vasconcelos, B.S. Cavada, R.A. Moreira Journal of the Science Food and Agriculture, 79, 815(1999), DOI:10.1002/(SICI)1097-0010(19990501)79:6<815::AIDJSFA290>3.0.CO;2-P 
RASĀYAN J. Chem.

Vol. 14 | No. 1 |155-160| January - March | 2021

10. N. N. Mahdi and Suharno, Forum Agribisnis: Agribusiness Forum, 9(2), 160(2019), DOI:10.29244/fagb.9.2.160-184

11. P. Matanjun, S. Mohamed, N.M. Mustapha, Journal of Applied Phycology, 21, 75(2009), DOI: $10.1007 / \mathrm{s} 10811-008-9326-4$

12. M. Firdaus, Yahya, G.R.H. Nugraha, D.D. Utari, IOP Conference Series: Earth and Environmental Science, 89, 01201(2017), DOI:10.1088/1755-1315/89/1/012011

13. https://www.iso.org/standard/11544.html

14. G.W. Latimer, Official Methods of Analysis of AOAC International, AOAC International, Gaithersburg, MD, USA (2016).

15. https://www.bsn.go.id/uploads/download/Booklet_tempe-printed21.pdf

16. S. Ciabotti, M.F.P. Barcelos, A.C.M. Pinheiro, P.R. Clemente, M.A.C. Lima, Food Science and Technology, 27, 643(2007), DOI:10.1590/S0101-20612007000300033

17. S. Lobban and J.C. Harrison, Seaweed Ecology and Physiology, Cambridge University Press, p.386 (1994), DOI:10.1007/BF02896669

18. W. A. Wijesinghe, Y. J. Jeon, Fitoterapia 83, 6, (2012), DOI:10.1016/j.fitote.2011.10.016

19. A. Jiménez-Escrig and F.J. Sánchez-muniz, Nutrition Research, 20, 4 (2000), DOI:10.1016/S02715317(00)00149-4

20. S. Gupta and N. Abu-Ghannam, Innovative Food Science and Emerging Technologies, 12, 4 (2011), DOI:10.1016/j.ifset.2011.07.004

21. N. Sakinah, E. Prangdimurti, and N.S. Palupi, Jurnal Teknologi dan Industri Pangan,30(2), 152(2019), DOI:10.6066/jtip.2019.30.2.152

22. I. M. P. L. V. O. Ferreira, O. Pinho, E. Vieira, J. G. Tavarela, Trends in Food Science \& Technology, 21, 2(2010), DOI:10.1016/j.tifs.2009.10.008

23. M. Astuti, A. Meliala, F.S. Dalais, and M.L. Wahlqvist, Asia Pacific Journal of Clinical Nutrition, 9, 322(2000), DOI:10.1046/j.1440-6047.2000.00176.x

24. M. Faisal, Saifullah and T. Mukhriza, Rasayan Journal of Chemistry, 12(3), 1151(2019), DOI: $10.31788 /$ RJC.2019.1235365

25. H. Lawless, Journal of Food Quality, 14, 33(1991), DOI:10.1111/j.1745-4557.1991.tb00046.x

26. A. Asngad, Suparti, P.B. Laksono, Jurnal Penelitian Sains dan Teknologi, 12, 1(2011).

27. D. Saha, S. Bhattacharya, Journal of Food Science Technology, 47, 6(2010), DOI:10.1007/s13197010-0162-6

28. https://www.soyinfocenter.com/HSS/tempeh1.php

29. R.W. Hutkins, Microbiology and Technology of Fermented Foods, John Wiley \& Sons, United States, p.441 (2008).

30. M. Kasprowicz-Potocka, P. Borowczyk, A. Zaworska, W. Nowak, A. Frankiewicz, and P. Gulewicz, Food Technology and Biotechnology, 54, 3(2016), DOI:10.17113/ftb.54.03.16.4459

[RJC-6014/2020] 